\title{
COMMUNICATION REVOLUTIONS THAT MARKED THE HISTORY OF EDUCATION. PROVERBS IN EDUCATION - THESES AND PARADOXES
}

\author{
Cezar Scarlat \\ PhD., Director, Doctoral School of Entrepreneurship, Business Engineering \& Management - \\ FAIMA, University "Politehnica” of Bucharest (Romania)
}

\begin{abstract}
As part of human society as a whole, the education system continues to play its role - addressing the newer needs of an increasingly technologized society (essentially new communication and information technologies - C\&IT). The education system, changing itself, has to answer to all changing needs and challenges of the contemporary society; and the solutions offered are, in general, technology-based solutions. This paper aims to offer a different prospective, looking backwards in history still focused forwards, on the educative role of the wisdom literature and proverbs in particular, as educative means - not as an alternative but as an additional, particular instrument to be used during the education process. Also, this does not entail, by any means, to undermine the role of new technologies in education. The author's approach is to survey the history of education from that standpoint of the history of humans' communication - which was definitely marked by several stepping-stones, actually four communication revolutions, namely: (i) language revolution; (ii) writing revolution; (iii) printing revolution; and (iv) contemporary e-communication revolution.

As part of the books of wisdom (books of knowledge) or independently, the proverbs always played an important educative role - as subtle yet solid and continuous, particular kind to educate - before invention of printing and even writing. Praising the collective and anonymous author as universal and immortal educator, the main objective of this paper is to launch four theses related to the proverbs' resilience, durability and continuity, as well as five paradoxes regarding the proverbs' dynamics.

The novelty of this paper, besides emphasizing the communication revolutions that impacted the history of education, consists of launching the concepts of the proverbs' theses and paradoxes - specifically the four theses related to the proverbs' resilience and the five paradoxes of the proverbs' dynamics.

The subject and research path initiated may, eventually, enlarge future research avenues, and/or provoke discussions among [higher] education strategists, policy makers, scholars and educators.
\end{abstract}

Keywords: Communication revolutions, communication and information technologies (C\&IT), proverbs and education, theses on the proverbs' resilience, paradoxes of the proverbs' dynamics.

\section{Stepping-stones that have marked the history of humans' communication and education}

According to Hawking (2001), the history of homo sapiens - human beings as we are - started about 150,000 years ago which is just $6 \%$ as compared to history of the genus homo (2.5 million years). Historians agree that the "history of sapiens is only a very small part of the history of humankind" and "we still know far more about ourselves than about other species of human beings, including several that have become extinct since we first walked the Earth" (Harari, 2014). After unremarkable first half of this history of sapiens, Harari notices a series of revolutions: (i) the cognitive revolution about 70,000 years ago - by when the fictional language has occurred and people started to behave more ingenious; starting from Eastern coast of Africa, they have spread across the planet; (ii) the agricultural revolution about 11,000 years ago - be when sapiens set to more stable domestic farming instead of hunt animals or gather fruits and vegetables; (iii) the scientific revolution about 500 years ago. Wiener (1989, p.46) has shared the same view on the scientific revolution, stressing the role played by inter-human communication: “ The last four hundred years are a special period in the history of the world. The pace at which changes during these years have taken place is unexampled in earlier history, as is the very nature of these changes. This is partly the result of increased communication ..." Or (op. cit.): "The thought of every age is reflected in its technique ... the eighteenth and nineteenth centuries constitute the age of steam engines, the present time is the age of communication and control." 
Amid highly respected opinions of top scholars in various science areas as astro-physics, history and cybernetics, for the purpose of our discourse, it is critically important to learn about the crucial points in the history of humanity that have marked its education goals and actors, means and processes - via communication: emergence of the language, writing, invention of printing, and e-communication.

The languages as articulate speaking have allowed earlier humans to communicate in a finer manner than by gestures and mimic ('non-verbal pre-language') or producing onomatopoeic sounds and phonemes, crying and howling, yelling and screaming ('wild non-articulated pre-language'). By writing - understood as handwriting - the messages could be transmitted 'as they were, carved in stone' at distances limited only by the transportation means available at that time, and - probably more important - over generations and periods of time limited only by the durability of the material support that was used for writing (stone, clay or wax tables, wood panels, sheep skin, bamboo strips, papyrus, paper and alike). Invention of printing was a real revolution (not accidentally contemporary to the scientific revolution) that increased significantly the capacity of one's writings 'as they are' to reach considerable larger numbers of individuals, in a more effective (unchanged message) and efficient manner (at a lot lower cost than hand-copying). Ultimately, the mass e-communication using new technologies for data generation, processing, transmission and storing (namely information and communication technologies - IT\&C) is the contemporary amazing phenomenon we are witnessing each fraction of second, with almost no time, space or other types of barriers. In other words - words of 'revolutions' - we might say that:

- The language revolution is actually cognitive revolution (i) - when the language development made exchange / sharing of information possible, and, consequently, made education possible.

- The writing revolution was probably one of the effects of agricultural revolution (ii), as early forms of writing emerged during primary phases of agricultural revolution. The writing made possible the transmission of information in time and at distance, and made possible the inception, diffusion and dissemination of education, by hand-written and hand-copied books - which were the teaching materials of the first schools, precursors of mid-age universities.

- The printing revolution was an early signal of the industrial revolution - the initial stage of the scientific revolution (iii). The productive book copying allowed institutional development of libraries, schools and universities as the centres of information and knowledge. These books were the main teaching materials that made possible the development of modern education.

- The e-communication revolution (or information revolution) is the hard-core of the scientific revolution (iii). It allowed unmatched development of technology that made possible e-production, e-transmission, e-processing, e-storage of e-books and virtual libraries, distance teaching and learning, new education technologies and alike - actually everybody's unlimited access to information and education - featuring the new type of universities of the near-future.

\subsection{Language revolution}

The point in time when the language has emerged is considered one of the hardest problems in science (Christiansen and Kirby, 2003) and a number of theories about appearance of language are subject to scientific debates (Tallerman and Gibson, 2012). Chomsky (1996), based on the discontinuity theory, argues that about 100,000 years ago the language faculty was the result of "a single chance mutation" that occurred in an individual's brain; the champions of continuity support the idea of gradual evolution from primitive proto-language that became the language proper to homo sapiens less than 200,000 years ago. Based on the analysis of phonemes (Atkinson, 2011), Perreault and Mathew (2012) suggested that language first evolved around 150,000-50,000 years ago. Harari (2014) speculates that development of language made humans able to think in abstract terms, cooperate in larger communities and exchange comments (gossiping). The language contributed to the cognitive revolution, by when the fictional language occurred and people started to behave more ingeniously. It probably was about the time when humans began to use metaphor-type expressions that eventually led to early proverbs.

\subsection{Writing revolution}

The archaeologists discovered limestone tablets with pictographic symbols dated back in 3500 $\mathrm{BC}$ in Mesopotamia - where the cuneiform writing was invented as well (3400-3300 BC) - followed by Egyptian hieroglyphic writing, and Chinese writing. The writing has marked the border of evolution from prehistory to history: "Prehistory is normally made to end (and history to start) with the appearance of writing" (Bonanno, 2005, p.6). The writing made the systematic education possible, transmitting knowledge by neat messages (literally "carved-in-stone", originally) in space and time. The history of handwritten or copied writings reports a notable progress from scrolls (or volumen) to codex shape (Lyons, 2013, p.8): "In the Christian world of the second and third centuries ... The codex was a book 
with pages that turned, instead of a long strip of material that unrolled ... The codex revolutionized the shape of the book itself ... that lasted for centuries."

Historians believe that in antiquity, because of general illiteracy, the books (op. cit., p.9) "were read aloud or declaimed to an audience by trained orators. Reading was a performance." The early [handwritten] books allowed the separation between individual and group teaching and learning.

\subsection{Printing revolution}

Invention of printing is one of the markers of the scientific revolution (by its influence on science and education development) as well as part of the industrial revolution (Scarlat, 2019, pp.46-47). Gutenberg is credited with invention of printing with moveable metal type (Mainz, in the 1440s) and the so-called Gutenberg Bible was the first book produced with moveable type in Europe by then. However, the metal type was used in Korea before Gutenberg, and the xylographic woodcut printing was common in China even earlier by the eleventh century (Lyons, 2013, p.58). One major effect of printing books in larger number of copies at a higher pace (rather than hand-copying) was definitely larger access to education; as result, the illiteracy has diminished. Per Lyons (op. cit., pp.9-10), "the so-called 'reading revolution' of the late eighteenth century saw an explosion of recreational literature and an expansion of the periodical press ... In the nineteenth century, the Western world achieved almost universal literacy." - which underlines the impact of printing on education. It is also the period when printed collections of proverbs have returned among the people as education means.

\subsection{E-communication revolution}

The mass e-communication using new technologies for data generation, processing, transmission and storing (namely information and communication technologies - IT\&C) is the contemporary phenomenon we are witnessing each fraction of second, with almost no time, space or other types of barriers. From Gutenberg printing to e-communication, from codex to e-books (still the e-books have codex shape!), from paper to e-memories, the mechanism and history of language (Wiener, 1989, pp.74) and communication have evolved and developed from man-to-man to man-to-machine and machine-to-man to machine-to-machine communication. Currently we talk about IoT (Internet of Things) which is basic machine-to-machine communication; so the computer networks and Internet are as well. Advanced research not only on phonetic but also semantic aspects of language will contribute to the not-far-away-future of IoB (Internet of Bodies/Brains). Will IoB be the next big thing in education?

The articulate speaking (language), writing, printing, and e-communication of knowledge have marked the development of education systems and processes - on all their dimensions: students, educators, teaching infrastructure and methods. Therefore, it is right to call these revolutionary steps in humankind history as education revolutions. It is also notable that each of them did not eliminate but necessarily included the previous one(s).

\section{Education by wisdom literature: books of knowledge \& proverbs}

In spite of their venerable millennial age, the universities are very young as compared to the age of homo sapiens (what is a millennium as compared to a period of 150 millennia of homo sapiens? or to a period of 70 millennia of cognitive homo sapiens?) The question is: what was before the precursors of universities (religious - either cathedral or monastic - schools), dating back in the $6^{\text {th }}$ century as Riché (1978) argued. It is behind the purpose of this chapter to review the history of school. However, it should be mentioned that first schools in antiquity (Marrou, 1948) appeared in Mesopotamia (by religious temples, to train the priests and scribes), China (as early as the $3^{\text {rd }}$ millennium BC), Egypt (by the pharaoh court, for the members of royal family and administrators). The access to these schools was limited - for the use of ruling families and religious elite (Lyons, 2013); thus most of the population was illiterate. Teaching was performed in groups, from magister to disciples, and the knowledge was transmitted by repeating and memorization. [Hand]-written/copied books were rare, most of them religious.

The Greek schools (as Pythagorean Brotherhood, Plato's Academy in Athens or Aristotle's Lyceum or Peripatetic School) were open to intellectual elites, and devoted to the study of sciences as geometry and astronomy as well as philosophy and rhetoric. It is very likely that, amid scarcity of books, magister was using proverbs as teaching aids - Aristotle mentioning already old proverbs in his writings. In ancient Rome, the rich families were able to hire private tutors for their children. According to Crenshaw (2000), in ancient rural communities, there also were lessons of life and civic education, transmitted orally, as education provided within family (by the family-wise to the younger members).

The religious commands and lessons of life frequently have merged: one of the oldest books, the Bible (religious per se), includes a chapter of lessons of life and civic education ('Book of Proverbs'). 
By tradition, the paternity of these proverbs goes to the wise king Solomon; however, Clements (2003) shows that the proverbs collected were generated in different periods, associated to a lifestyle that lasted for about a millennium; therefore they were not strictly generated in a single restricted geographic area. Yet Alter (2010) argues that the source of proverbs is older: a collection of old Egyptian proverbs - 'The Teaching of Amenemope' or 'Wisdom of Amenemope' (the $2^{\text {nd }}$ millennium BC) - that inspired the 'Book of Proverbs' via a translation in Aramaic language (Ruffle, 1995). According to Smothers (2000), the books of wisdom were rather popular in the Oriental antiquity. However, Tucker (2000) argues that, in ancient Israel, the wisdom literature was quite developed but limited to the royal court (for the education of the members of the royal family) as well as several schools for youth education.

Besides wisdom literature, the proverbs played an important educative role - not as an alternative but as subtle yet solid and continuous, particular kind to educate - before invention of printing and even writing. Therefore, we have to praise the collective and anonymous author as universal and immortal educator. In this respect, Scarlat (2019, pp.53-55) enounces four theses related to the proverbs' resilience, durability and continuity (Table 1).

Table 1. The Four Theses - related to the proverbs' resilience and durability (Scarlat, 2019, pp.53-55).

\begin{tabular}{|l|l|}
\hline \multicolumn{1}{|c|}{ Communication revolutions } & \multicolumn{1}{c|}{ The Theses } \\
\hline $\begin{array}{l}\text { Language revolution: emergence of } \\
\text { articulate speaking (language) }\end{array}$ & $\begin{array}{l}\text { The first thesis: The proverbs (anonymous and collective life } \\
\text { experience lessons transmitted orally) preceded the invention of } \\
\text { writing - as primary education means for early humans. }\end{array}$ \\
\hline $\begin{array}{l}\text { Writing revolution: invention of } \\
\text { writing }\end{array}$ & $\begin{array}{l}\text { The second thesis: The proverbs (anonymous and collective life } \\
\text { experience lessons transmitted orally) continued to be used even after } \\
\text { the invention of writing. Proverbs were initially used for the education } \\
\text { of royal and religious elites. }\end{array}$ \\
\hline $\begin{array}{l}\text { Printing revolution: invention of } \\
\text { printing }\end{array}$ & $\begin{array}{l}\text { The third thesis: The proverbs (anonymous and collective life } \\
\text { experiences transmitted orally) continued to be used even after the } \\
\text { invention of printing - mostly for the basic education of increasingly } \\
\text { larger population. } \\
\text { The printed books made possible the development of modern } \\
\text { universities. }\end{array}$ \\
\hline $\begin{array}{l}\text { E-communication revolution: mass } \\
\text { communication using new } \\
\text { e-technologies for data generation, } \\
\text { transmission, processing, and storing } \\
\text { (information technology and } \\
\text { communications - IT\&C) }\end{array}$ & $\begin{array}{l}\text { The fourth thesis: The proverbs (anonymous and collective life } \\
\text { experiences transmitted orally) continue to be used even after the } \\
\text { emergence of IT\&C - which facilitates mass access and accelerates } \\
\text { their transmission. Proverbs are still used as teaching aids even in } \\
\text { university degree programmes. }\end{array}$ \\
\hline \multicolumn{2}{|l}{} \\
\hline
\end{tabular}

Using the same framework of communication \& education revolutions, based on two-by-two matrix with two dimensions of analysis - source of proverbs ("generated by ...") and their destination ("used by ...") - Scarlat (2015, pp.39-44; 2019, pp.55-62) identifies five paradoxes: Paradox of the proverbs' dissemination; Paradox of the proverbs' enrichment; Paradox of the proverbs' secularization; Paradox of proverbs' use by the intellectual elite; Paradox of the proverbs' value.

These paradoxes observe the proverbs' dynamics, during different historical ages, along their millennial way from \{generated by the royal and religious elites for their own use to \{generated by masses for their own use $\}$.

\section{Conclusions}

Universities were the focal point of higher education for more than thousand years - which is an amazing example of stability. Indeed, one reason behind their millennium-long chronicle is the existence of printed books - as their developments have paralleled.

Along centuries, the proverbs have had an educative function in that respect of principles of moral and healthy life, common sense, and life lessons learnt, sometimes with a grain of humour. In particular, the proverbs can be used as teaching aids even in the area of the 'younger' science of management (Scarlat, 2008). Referring to the case of entrepreneurship education by proverbs, Afendras (2019) observes that "Family business was of course a very important locus for handing down entrepreneurial skills, as was child labour. The learning model here was internship and the transmission often included storying and proverbs. And it is precisely for this reason that societies through the ages developed communicative mechanisms to transmit condensed experience about everything that mattered to succeeding generations, before colleges, business schools and Institutes of Management: by telling 
stories of personal experience, passing down folktales and proverbs, more condensed, epigrammatic forms of this process." (op. cit., pp.230-231).

The novelty of this paper - besides emphasizing the communication revolutions that impacted the history of education as well as the role of proverbs as teaching aids in modern education - consists of launching the concepts of the proverbs' theses and the proverbs' paradoxes - specifically the four theses related to the proverbs' resilience and the five paradoxes of their dynamics - based on the analysis of a two-by-two GU matrix \{proverbs' Generation, proverbs' Use\}.

The concepts launched as well as the subject and research path initiated may, eventually, enlarge and stimulate future research avenues - as trans- and/or inter-disciplinary studies, and/or provoke discussions among [higher] education strategists, policy makers, scholars and educators.

\section{References}

Afendras, E.A. (2019). And then there were Business Schools ... And Institutes of Management. And Globalisation. And before? In C. Scarlat, C. O sută de proverbe ale Românilor pentru 100 de ani de management modern [One Hundred Proverbs of the Romanians for 100 years of Modern Management] (pp.230-231). Bucharest, Romania: Ed. Niculescu.

Alter, R. (2010). The Wisdom Books: Job, Proverbs, and Ecclesiastes. A translation with commentary. New York, USA: W.W. Norton \& Company.

Atkinson, Q.D. (2011). Phonemic diversity supports a serial founder effect model of language expansion from Africa. Science, 332(6027), pp.346-349.

Bonanno, A. (2005). Malta. Phoenician, Punic, and Roman. Malta: Midsea Books Ltd.

Chomski, N. (1996). Powers and Prospects. Reflections on human nature and the social order. London, UK: Pluto Press.

Christiansen, M.H. \& Kirby, S. (2003). Language evolution: the hardest problem in science? In M.H. Christiansen \& S. Kirby (Eds.), Language evolution. Oxford, UK: Oxford University Press.

Clements, R.E. (2003). Proverbs. In J.D.G. Dunn \& J.W. Rogerson (Eds.), Eerdemans Commentary of the Bible. Grand Rapids, MI, USA / Cambridge, UK: Eerdemans Publishing.

Crenshaw, J. (2000). Unresolved Issues in the Wisdom Literature. In H.W. Ballard Jr. \& W.D. Tucker Jr. (Eds.), An Introduction to Wisdom Literature and the Psalms, Festschrift Marvin E. Tate. Macon, GA, USA: Mercer University Press.

Harari, Y.N. (2014). Sapiens: A Brief History of Humankind. London, UK: Harvill Secker.

Hawking, S. (2001). The Universe in a Nutshell. The inspiring sequel to A Brief History of Time. London, UK: Bantam Press.

Lyons, M. (2013). Books. A Living History. London, UK: Thames \& Hudson.

Marou, H.I. (1948). Histoire de l'Education dans l'Antiquité. Paris, France: Editions du Seuil.

Perreault, C., Mathew, S. (2012). Dating the Origin of Language Using Phonemic Diversity. PLoS One, 7(4), published online 2012 April 27. Retrieved July 6, 2019 from: https://www.ncbi.nlm.nih.gov/pmc/articles/PMC3338724/

Riché, P. (1978). Education and Culture in the Barbarian West: From the Sixth through the Eighth Century. Columbia, SC, USA: University of South Carolina Press.

Ruffle, J. (1995). The Teaching of Amenemope and its Connection with the Book of Proverbs. In R.B. Zuck (Ed.), Learning from the Sages; Studies on the Book of Proverbs (pp.293-331). Baker Books.

Scarlat, C. (2008). Learning Business, Management, and Entrepreneurship by Proverb Cases: 21 Romanian Proverbs. SPACE Journal Advances in Higher Education, 1(1), pp.77-88.

Scarlat, C. (2015). Cartea cu proverbe de management [The Book with Management Proverbs]. Bucharest, Romania: Ed. Printech.

Scarlat, C. (2019). O sută de proverbe ale Românilor pentru 100 de ani de management modern [One Hundred Proverbs of the Romanians for 100 years of Modern Management]. Bucharest, Romania: Ed. Niculescu.

Smothers, T. (2000). Biblical Wisdom in its Ancient Middle Eastern Context. In H.W. Ballard Jr. \& W.D. Tucker Jr. (Eds.), An Introduction to Wisdom Literature and the Psalms, Festschrift Marvin E. Tate. Macon, GA, USA: Mercer University Press.

Tallerman, M. \& Gibson, K.R. (2012). The Oxford handbook of languages evolution. Oxford, UK: Oxford University Press.

Tucker, W.D. (2000). Literary Forms in the Wisdom Literature. In H.W. Ballard Jr. \& W.D. Tucker Jr. (Eds.), An Introduction to Wisdom Literature and the Psalms, Festschrift Marvin E. Tate. Macon, GA, USA: Mercer University Press.

Wiener, N. (1950; 1989). The Human Use of Human Beings. Cybernetics and Society. London, UK: Free Association Books. [First published 1950, Boston, MA, USA: Houghton Mifflin. Reviewed version published in 1989, with a new Introduction by Steve J. Heims]. 